\title{
The Influence of Financial Information of Charity Foundations on Donations: An Empirical Test
}

\author{
Xiaoxia Xie \\ $\mathrm{PhD}$, Lecturer, School of Humanities and Social Science of \\ Beihang University \\ Beijing, China \\ xiexx@buaa.edu.cn \\ xie.xiaoxia@gmail.com
}

\author{
Yonghong Ding \\ Student, School of Economic and management of Beihang \\ University \\ Beijing, China \\ 547185080@qq.com
}

\begin{abstract}
Public officials have recently sought increased regulations of financial disclosure of charitable organizations as a means of improving charity transparency .One subject of this study is to examine whether it exists some important financial information affecting donations to charitable foundations. Further, this study also provides some empirical research evidence of financial information affecting donations to charitable foundations. The paper discusses the influence of different financial information of public and non-public offering charitable foundations on different type donations. The empirical analyses indicate that three main financial information of public offering charitable foundations has influence on both of individual donations and institution donations, which includes the financial information of charity projects, donation income and investment income. These three main financial information of donation income, total assets, and income concentration of non-public offering charitable foundations has effect on both of individual donations and institution donations. By comparison individual donations can be easier to be influenced by the above mentioned financial information. When an institution decides to donate to public offering charitable foundations, it will consider much more fundraising risk information than one person decides to donate to the public offering charitable foundations.
\end{abstract}

Keywords-charity foundations; financial information; influence; donations

\section{INTRODUCTION}

This paper analyzes the characters of financial information of charitable foundations in China. This paper examines the financial information determinants of donations that can be used to decide to donate in China. This paper examines the different influence of all kinds of financial information of public and non-public offering charitable foundations on individual donations and institution donations. This paper analyzes main financial information that may influence the decision of individual and institution donations in China. This empirical research basis in financial information disclosure affecting donations in China has not been the focus of study in the existing literature.

One objective of this study is to ascertain whether the financial information has influence on individual donations and institution donations. Whether existing some financial information is important for individuals and institutions to make decision to donate has been explored. But this paper has not explored how to improve the financial information disclosure of charitable foundations, and this study seeks to inform this ongoing policy debate. This paper is also motivated by the theory that effective financial information disclosure will be useful to resolve the information asymmetric problems between internal management and external stakeholders. The empirical analysis first examines the extent to which financial information disclosure of Chinese charitable foundations has influence on the individual donations and institution donations. It is expected that some financial information has important influence on donations. This expectation is largely supported by the result. It testifies the financial information is useful for an institution and an individual to make decision to donate.

The information of annual personal donations, institution donations and financial ratio can be obtained from charitable foundations' annual reports. We exam a sample of 601 Chinese charitable foundations to see whether individual donations and institution donations are associated with the financial information of charitable foundations. We build six models to analyze the influence of financial information on donations of public and non-public offering charitable foundations.

Our results show that three type financial information has influence on total donations, which includes the financial information reflecting fundraising capability, operating funds capability and resisting risk capability. Models are tested on a sample of 601 Chinese charitable foundations ascertain these three type financial information that has influence on individual donations and institution donations.

The results of this study should be of interest to policymakers concerned with the use of annual report of charitable foundations by donors and other stakeholders. Because of the not-for-profit sector of charitable foundations, whether the financial information disclosure can satisfy the needs of all kinds of donors is the most important. The financial information disclosure of charitable foundations is a guideline that can help persons and institutions to make donation decisions. So financial information disclosure of charitable foundations may have influence on the allocation of scarce charity resources. Different financial ratios not only reflect the conditions of charitable foundations, but also change the views of donors. According to the information desire of all kinds of donors to disclose financial information, it will be in favor of charitable foundations' fundraising.

The remainder of the paper is organized as follows: the next section reviews the existing literature and begins with a 
brief discussion of information desired or used by donors. Subsections present prior research using economic models of giving and an overview of charitable foundations' financial information disclosure systems with emphasis on different research methods. The next major section presents the hypotheses, methodology, and sample selection process. The results, limitations and conclusions round out the discussion.

\section{LITERATURE REVIEW}

According to the statistics by Ministry of Civil Affairs of the People's Republic of China, there are currently over 2500 charitable foundations registered. According to the core data issued by China Charity and Donation Information Center, total contributions were nearly RMB 84.5 billions in 2011.

The theory of Information disclosure is a comprehensive theory system, which involves agency theory, asymmetry of information theory, signaling theory and so on. Today it is still lack of an authoritative and comprehensive theory systems(Verrecchia,2001;Dye,2001; Healy and Palepu,2001) .An asymmetry of information referred to the uneven and asymmetric distribution state when information was showed to some associated economic individuals. It was a information situation where some participants had more information than the others (Akerlof, 1970). An asymmetry of information also referred that the market participants had unequal information set (Chia-Wu Lu,et al.,2010). The different information disclosure will have different effect on the decision-making of information users. (Heflin,2005; Teresa P.Gordon,2009) .A lot of research has proved that information disclosure can effectively reduce asymmetry of information .Improving the level of mandatory information disclosure (agerman and Healy, 1992; Leuz and Verrecchia, 2000) and voluntary information disclosure (Healy et al.1995; Heflin et al.2005) also help to reduce asymmetry of information. The profit-making organizations always use information disclosure to satisfy the demands of information users so as to reduce asymmetry of information (Verrecchia,2001). The different content of information disclosure will have different effect on the decisions of information users (Baber, 2001; Bradley, 2003). It is very difficult for charitable foundations, as the typical non-profit organizations, to testify the effectiveness on donations (Gordon and Khumawala,1999). In a field-based study, Parsons (2007) found that a donor's exposure to positive accounting information during fundraising appeals directly influenced donations. In a laboratory setting involving a very small donation, $39 \%$ of donors were willing to view financial information to help them decide on the recipient(Parsons,2006).

Effective accounting report will have influence on the donors and users of financial reports. The donors prefer to donate when they have enough information (Gordon, 1999). These potential donors classified the financial information, especially about the information of charity project expense ratio which plays an important role in the donation process (Khumawala and Gordon, 1997). Charity officials and auditors think that the donors take the financial information as an important factor to make donation decisions (Hyndman, 1991, 1990). Donors who decide to donate mainly depend on the information (Hansmann, 1980). It exists a lot of reasons for individual donations, which include the religious, spiritual beliefs, social pressure, and so on (Gordon and Khumawala, 1999).

The Evaluated ratings of charity organization will has an positive influence on donation (Gordon et al, 2009). Good reputation of charitable organizations will improve the donations (Eckel and Gorssman, 2003). The size of the non-profit organization is also an important factor to influence donations (Tinkelman, 1999). The government can improve the reliability of the information disclosure of non-profit organization so as to improve the donations (Calabrese, 2011). The cost of raising funds has a positive influence on the non-profit organization's donations (Teinkelman, 1999). The charity organization's sustainable management has influence on donations (Frumkin and Kim, 2001). The charitable organizations which have a better financial stability will receive more donations. The donors tend to donate to the charitable organizations which have a low operation costs (Parsons and Truseel, 2008).

Although some Chinese researchers did some research on the information disclosure of non-profit organizations, they didn't completely analyze the influence of financial information of charitable foundations on donations in China. At the same time, the current results of information disclosure of charitable organizations were mainly concluded by theoretic analyses, which didn't provide empirical evidence. There is also lack of the empirical research of information disclosure of charitable organizations in China. A lot of results of theoretic analyses of information disclosure of charitable organizations in China need to be confirmed by an empirical research.. So I decide to do the empirical research on the influence of financial information of charitable foundations on donations. One object is to try to find the relations between financial information and donations. The other object is to confirm the theoretic analyses results by giving some empirical evidence.

\section{METHOD}

Based on the existing literature, we already know that there is relationship between price, fundraising expenditures, and charitable donations. If some financial information is used by donors, we anticipate that the financial information reflecting the income of charitable foundations would produce an incremental change in donations. At the same time because of fundraising cost existing, we anticipate that the financial information reflecting the expenditure of charitable foundations would have an opposite influence on donations. We specifically test the following research hypotheses, stated in the alternative form:

H1: The financial information reflecting the charity income structure is associated with a positive percentage change in contributions to charitable foundations.

$\mathrm{H} 2$ : The financial information reflecting the expenditure ratio is associated with a negative percentage change in contributions to a charitable foundations.

The charity organizations will face bigger risk and have disadvantage to obtain various charity resource with the higher income concentration. We specifically test the following research hypotheses, stated in the alternative form: 
H3: The financial information reflecting income concentration of charitable foundations will have a negative influence on donations.

We can divide the donations into two kinds which include individual donations that mainly come from personals' contributions, and institution donations that mainly come from corporate donations. These two stakeholders have been differently influenced by financial information because of the different donations' motivation. The motivation of personal donations may be of religious belief, the human nature glory, altruism orientation, and so on.(Gordon\&Khumawala,1999; List\&Lucking - Reiley, 2002; Eckel\&Gorssman, 2003; Altaf et al., 2010; ZhaoXiaoQin, WanDi Fang, 2011). But institution donations may be based on external compensatory, advertisement need, reducing agent problems, and so on. (ChenXiaoLin, WeiXueJiang, 2011). So the financial information of different charitable foundations will have different effects on the individual donations and institution donations. According to the Foundation Management Regulations issued by the state council in 2004, we can divide foundations into two types-public offering charitable foundations and non-public offering charitable foundations . The public offering charitable foundations are allowed to raise funds from the public according to the Foundation Management Regulations. The non-public offering charitable foundations are not allowed to raise funds from the public. We specifically test the following research hypotheses, stated in the alternative form:

H4: The financial information reflecting income structure of public and no-public offering charitable foundations will have positive influence on individual donations. The financial information reflecting income concentration will have a negative influence on individual donations.

H5: The financial information reflecting income structure of non-public offering charitable foundations has positive influence on institution donations. The financial information reflecting the expenditure will have a negative influence on the institution donations. The financial information reflecting income concentration will have a negative influence on institution donations. The financial information of non-public offering charitable foundations has a greater influence on institution donations than on the individual donations.

\section{DATA}

The primary data used in this paper comes from the public data of Ministry of Civil Affairs of the People's Republic of China that covers fiscal years 2005-2010.To test our hypothesis, we obtained the names of all organizations listed on the Ministry of Civil Affairs of the People's Republic of China website .From this list of 623 organizations, we selected the a sample of 601 organizations. ${ }^{1}$ The analysis is limited to charitable foundations which have already disclosed their reports from 2005, and the sample contains 601 observations. Table 1 details the data editing process.

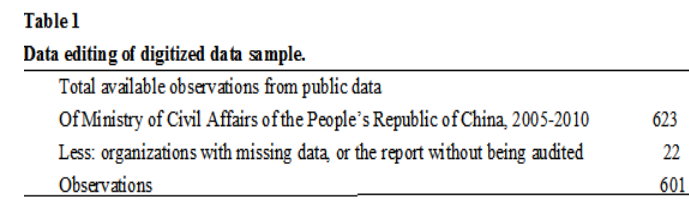

\section{DEFINING THE VARIABLES}

A summary of all variables is included in Table 22.In order to ascertain the different influence of financial information on different donation types; in this paper we analyze the different influence of financial information of charitable foundations on total donations, individual donations and institution donations.

\begin{tabular}{ll} 
Table 2 & \\
Variable definitions & Description \\
\hline Variable name & $\begin{array}{l}\text { Natural log of total donations for charitable } \\
\text { foundations } i\end{array}$ \\
\hline Total donations (TD) & $\begin{array}{c}\text { Natural log of individual donations for } \\
\text { charitable foundations } i\end{array}$ \\
Natural log of institution donations for \\
Individual donations (PD) \\
charitable foundations $i$
\end{tabular}

The first column in Table 3 displays the descriptive statistics for key variables. The next column in Table 3 shows the type of charitable foundations. The data suggests that the average ATC in public offering charitable foundations is $84.63 \%$, while the average ATC in non-public offering charitable foundations is $86.55 \%$.It means that the operating activity expenditure is the main expense of Chinese charitable foundations expense. The data suggests that the average percentage of main public project income accounting for the proportion of total revenue of public offering charitable foundations is the largest, which is reaching to $114.42 \%$. The average of donations income accounting for total revenue in public offering charitable foundations is $76.19 \%$, while the average DTR in non-public offering charitable foundations is $70.88 \%$. The data indicates that the donations income is the main resource of public and

\footnotetext{
${ }^{1}$ In order to make the analytical information more accountable, we select the organizations which have the report audited as sample.

${ }^{2}$ Following previous studies (Tinkelman, 1999;Parsons and Trussel,2008;zhangbiao,2009)with current financial information disclosure of Chinese charitable foundations, we select these variables in table 2 .
} 
non-public offering charitable foundations(see mean on Table 3).

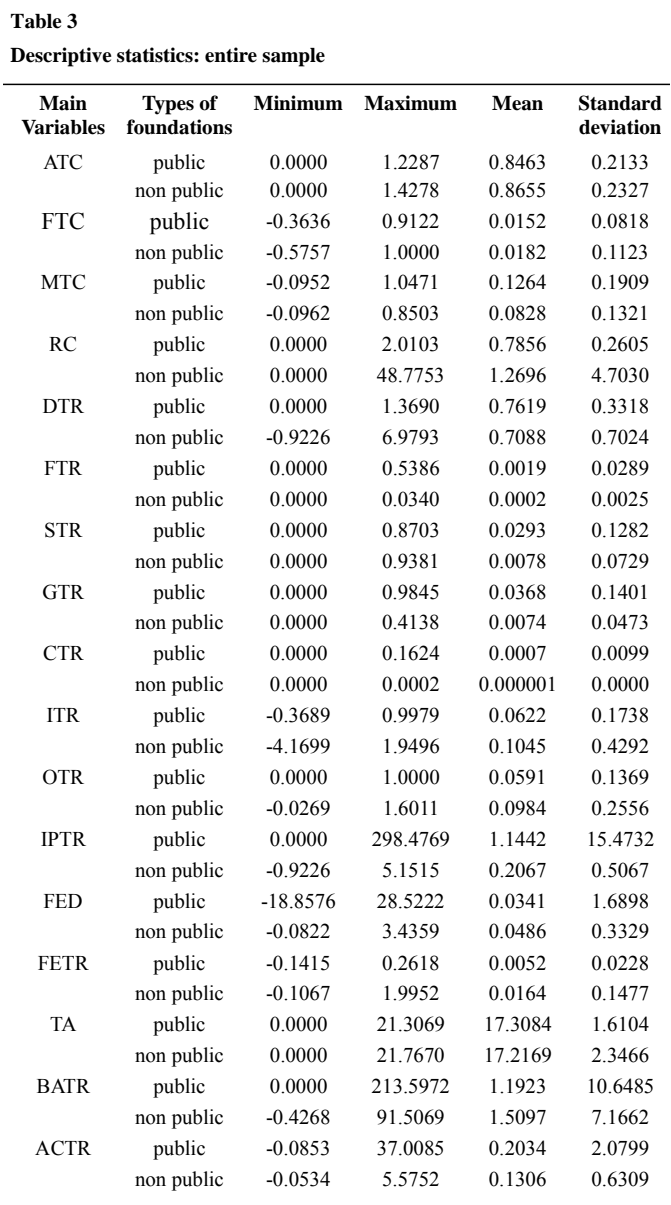

\section{EMPIRICAL ANALYSIS AND RESULTS}

\section{A. Specification of models}

To test our hypotheses, we primarily use financial data from Ministry of Civil Affairs of the People's Republic of China website. The data can be analyzed by three different specifications: the dependent variable can be examined as total donations, individual donations and institution donations. Instead of replicating the OLS regression model used in earlier research by Trussel and Parsons (2008), we directly look at percentage of all kinds of financial ratio specifically, we consider to avoid the multicollinearity problems between variables, we use stepwise regression method to select variables to establish regression models. Considering the different characters of financial information of public and non-public offering charitable foundations, we build model (1) model (2) and model (3) to analyze the influence of financial information of public offering charitable foundations on total donations, individual donations and institution donations as followings

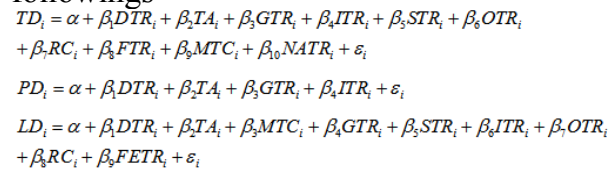

model (4) ,model (5) and model (6) to analyze the influence of financial information of non-public offering charitable foundations on total donations, individual donations and institution donations as

$$
\begin{aligned}
& T D_{i}=\alpha+\beta_{1} D T R_{i}+\beta_{2} R C_{i}+\beta_{3} T A_{i}+\beta_{4} N A T R_{i}+\beta_{5} I T R_{i}+\beta_{6} I P T R \\
& +\beta_{7} C T R_{i}+\beta_{5} G T R_{i}+\varepsilon_{i} \\
& P D_{i}=\alpha+\beta_{1} T A_{i}+\beta_{2} R C+\beta_{3} D T R_{i}+\varepsilon_{i}
\end{aligned}
$$

followings: $\quad L D_{i}=\alpha+\beta_{1} D T R_{i}+\beta_{2} R C_{i}+\beta_{3} T A_{i}+\varepsilon_{i}$

Among them, the subscript i means the sample charitable foundation, $\varepsilon_{i}$ for the error term. The model (1) and model (4) mainly research on the influence of financial information of public and non-public offering charitable foundations on total donations. TDi is the dependent variable in the model (1) and model (4). PDi is the dependent variable in model (2) and model (5).LDi is the dependent variable in model (3) and model (6). We select the financial information variable mainly reflecting the income source information (DTR, GTR, ITR, STR, OTR, FTR), reflecting total assets information (TA), reflecting income concentration information (RC), reflecting net assets information (NATR), reflecting expenditure information (MTC) as the independent variables in model (1). We select the financial information variable mainly reflecting income source information (DTR, GTR, ITR), reflecting total assets information (TA)as the independent variables in model(2). We select the financial information mainly reflecting income source information (DTR, GTR, STR, ITR, OTR),reflecting total assets information(TA),reflecting income concentration information(RC), reflecting expenditure information (MTC, FETR) as independent variables in model(3).We select the financial information mainly reflecting source income information (DTR, ITR, IPTR, CTR, GTR), reflecting the income concentration information (TC), reflecting the total assets information (TA), reflecting the net assets information (NATR)as independent variables in model (4) . We select the financial information mainly reflecting source income information (DTR), reflecting the income concentration information ( $\mathrm{RC}$ ), and reflecting the total assets information (TA) as independent variables in model (5). We select the financial information mainly reflecting source income information (DTR), reflecting the income concentration information ( $\mathrm{RC}$ ), and reflecting the total assets information (TA) as independent variables in model (6).

\section{B. The result of regression analysis}

1) The influence of financial information of public and non-public offering charitable foundations on total donations.

Table 4 displays the results for model(1)and model(4).The model(1) is statistically significant with adjusted R2 of 0.836.Consistent with $\mathrm{H} 1$,H2 and $\mathrm{H} 3$,for public offering charitable foundations, the variable DTR has a coefficient of 19.932 with a t-statistic of 26.187 .The variables representing the financial information reflecting the charity income structure are positive and significant while the variable MTC representing the financial information reflecting expenditure has a coefficient of -2.112 with t-statistic of -4.001 . The variable $\mathrm{RC}$ has a coefficient of -4.391 with t-statistic of -6.701 , which is negative and significant.

The model(4) is statistically significant with adjusted R2 of 0.738. However for non-public offering charitable foundations, 
the variable CTR has a coefficient of -48318.683 with a t-statistic of -2.328 , which is abnormal. It can not verify the H1 for non-public offering charitable foundations. Consistent with $\mathrm{H} 3$, for non-public offering charitable foundations, the variable

$\mathrm{RC}$ has a coefficient of -1.379 with a t-statistic of -14.282 .

\begin{tabular}{|c|c|c|}
\hline $\begin{array}{l}\text { Regression } \\
\text { model(4) }\end{array}$ & results for & model(1) and \\
\hline $\begin{array}{c}\text { Independent } \\
\text { variable }\end{array}$ & Model(1) & Model(4) \\
\hline \multirow[t]{2}{*}{$\alpha$} & -10.654 & -2.684 \\
\hline & $(-9.54 * *)$ & $(-1.422)$ \\
\hline \multirow[t]{2}{*}{ DTR } & 19.932 & 12.891 \\
\hline & $\left(26.187^{* * *}\right)$ & $(18.841 * *)$ \\
\hline \multirow{2}{*}{ TA } & 0.690 & 0.427 \\
\hline & (1 $1.479 * *)$ & $(3.910 * *)$ \\
\hline \multirow[t]{2}{*}{ GTR } & 13.582 & 10.675 \\
\hline & $(15.941 * *)$ & $(1.991 * *)$ \\
\hline \multirow[t]{2}{*}{ ITR } & 11.289 & 3.787 \\
\hline & $(14.858 * *)$ & $(4.489 * *)$ \\
\hline IPTR & - & $\begin{array}{c}2.666 \\
(3.952 * *)\end{array}$ \\
\hline \multirow[t]{2}{*}{ STR } & 11.428 & - \\
\hline & $\left(12.865^{* *}\right)$ & \\
\hline OTR & $\begin{array}{c}10.095 \\
\text { (11.989**) }\end{array}$ & - \\
\hline CTR & - & $\begin{array}{c}-48318.683 \\
(-2.328 * *)\end{array}$ \\
\hline $\mathrm{RC}$ & $\begin{array}{c}-4.391 \\
(-6.701 * *)\end{array}$ & $\begin{array}{c}-1.379 \\
(-14.282 * *)\end{array}$ \\
\hline FTR & $\begin{array}{c}13.098 \\
\left(4.106^{* *}\right)\end{array}$ & - \\
\hline MTC & $\begin{array}{c}-2.112 \\
(-4.001 * *)\end{array}$ & - \\
\hline NATR & $\begin{array}{c}-0.001 \\
(-3.941 * *)\end{array}$ & $\begin{array}{c}-0.006 \\
(-2.424 * *)\end{array}$ \\
\hline Adjusted $R^{2}$ & 0.836 & 0.738 \\
\hline F-statistic & 210.280 & 67.100 \\
\hline p-value & 0.000 & 0.000 \\
\hline
\end{tabular}

Note: The numbers in italics below the coefficients are t-statistics based on standard errors calculated using the Huber/White/sandwich estimator of variance. The sample size is 601 observations. ${ }^{* *}$ significant at $5 \%$

The influence of financial information of public and non-public offering charitable foundations on individual donations.

While the change specification controls for dependent variables that only represent individual donations, the linear model (2) and model (5) are the specification models that have study the influence of the financial information on individual donations. Table 5 reports the result of linear model(2)and model(5).The first column presents our basic levels model(2)and model(5):all coefficients are significant and the adjusted R2 of model(2) is 0.243 and the adjusted R2 of model(5) is 0.213 .Consistent with $\mathrm{H} 4$,we find that an increase or decrease in financial information reflecting income structure of public and non-public offering charitable foundations is associated with a corresponding increase or decrease in the level of individual donations(the coefficient of DTR of model(2) is 10.013 with a t-statistic of 9.208 , the coefficient of DTR of model(5) is 5.904 with a t-statistic of 5.149, the coefficient of GTR is 6.809 with a t-statistic of 3.013,the coefficient of RC is -0.746 with a t-statistic of -4.382 .

\begin{tabular}{|c|c|c|}
\hline $\begin{array}{l}\text { Regression } \\
\text { model(5) }\end{array}$ & results & model(2) \\
\hline $\begin{array}{c}\text { Independent } \\
\text { variable }\end{array}$ & Model(2) & Model(5) \\
\hline \multirow[t]{2}{*}{$\alpha$} & -14.939 & -11.564 \\
\hline & $(-4.762 * *)$ & $(-3.297)$ \\
\hline \multirow[t]{2}{*}{ DTR } & 10.013 & 5.904 \\
\hline & $(9.208 * *)$ & $(5.149 * *)$ \\
\hline \multirow[t]{2}{*}{ TA } & 0.891 & 0.900 \\
\hline & $(4.857 * *)$ & $(4.407 * *)$ \\
\hline \multirow[t]{2}{*}{ GTR } & 6.809 & - \\
\hline & $(3.013 * *)$ & \\
\hline \multirow[t]{2}{*}{ ITR } & 4.257 & - \\
\hline & $(2.161 * *)$ & \\
\hline \multirow[t]{2}{*}{$\mathrm{RC}$} & - & -0.746 \\
\hline & & $(-4.382 * *)$ \\
\hline Adjusted $R^{2}$ & 0.243 & 0.213 \\
\hline F-statistic & 33.918 & 18.000 \\
\hline$p$-value & 0.000 & 0.000 \\
\hline
\end{tabular}

Note: The numbers in italics below the coefficients are t-statistics based on standard errors calculated using the Huber/White/sandwich estimator of variance. The sample size is 601 observations. ${ }^{* *}$ significant at $5 \%$

The influence of financial information of public and non-public offering charitable foundations on institution donations.

Interestingly, the analysis reveals a slightly different finding for the sensitivity of the main result to different type donations. In contrast to the change analysis of the influence of financial information on different type donations, the level of donations varies across the total donations, individual donations and institution donations. Table 6 reports the results of linear model(3)and model(6).The first column presents our basic levels model(3)and model(6):all coefficients are significant and the adjusted R2 of model(3) is 0.382 and the adjusted R2 of model(6) is 0.505 .Consistent with H5,we find that all of financial information reflecting income structure of public and non-public offering charitable foundations is positive associated with a corresponding increase or decrease in the level of institution donations. We find that all of financial information reflecting the expenditure has a negative influence on institution donations(the coefficient of FETR is -23.722 with a t-statistic of -2.170 ,the coefficient of MTC is -2.809 with a t-statistic of -1.981). The financial information reflecting income concentration has a negative influence on institutions(the coefficient of RC of model(3) is -5.141 with a t-statistic of -2.975 , the coefficient of RC of model(6) is -1.196 with a t-statistic of -8.587). Table 5 and Table 6 report that the financial information of non-public offering charitable foundations has a greater influence on institution donations than on the individual 


\begin{tabular}{|c|c|c|}
\hline $\begin{array}{l}\text { Regression } \\
\text { odel(G) }\end{array}$ & results & model(3) \\
\hline $\begin{array}{c}\text { Independent } \\
\text { variable }\end{array}$ & Model(3) & Model(G) \\
\hline$a$ & $\begin{array}{c}-16.176 \\
(-5.377 *)\end{array}$ & $\begin{array}{c}-10.353 \\
(-3.607 *)\end{array}$ \\
\hline DTR & $\begin{array}{c}17.500 \\
(8.712 * *)\end{array}$ & $\begin{array}{c}11.067 \\
(11.792 * \text { ) }\end{array}$ \\
\hline TA & $\begin{array}{c}1.095 \\
(6.749 * *)\end{array}$ & $\begin{array}{c}0.900 \\
(5.384 * *)\end{array}$ \\
\hline GTR & $\begin{array}{c}10.986 \\
(4.821 *)\end{array}$ & - \\
\hline ITRR & $\begin{array}{c}7.744 \\
(3.812 * *)\end{array}$ & - \\
\hline STR & $\begin{array}{c}9.905 \\
(4.168 * *)\end{array}$ & - \\
\hline OTR & $\begin{array}{c}8.308 \\
(3.763 * *)\end{array}$ & - \\
\hline RC & $\begin{array}{c}-5.141 \\
(-2.975 *)\end{array}$ & $\begin{array}{c}-1.196 \\
(-8.587 * *)\end{array}$ \\
\hline FETR & $\begin{array}{c}-23.722 \\
(-2.170 * *)\end{array}$ & - \\
\hline MTC & $\begin{array}{c}-2.809 \\
(-1.981 *)\end{array}$ & - \\
\hline $\begin{array}{l}\text { Adjusted } \\
\text { R2 }\end{array}$ & 0.382 & 0.505 \\
\hline $\begin{array}{c}\text { F-statistic } \\
\text { p-value }\end{array}$ & $\begin{array}{c}29.234 \\
0.000\end{array}$ & $\begin{array}{c}64.885 \\
0.000\end{array}$ \\
\hline
\end{tabular}

Note: The numbers in italics below the coefficients are t-statistics based on standard errors calculated using the Huber/White/sandwich estimator of variance. The sample size is 601 observations. ${ }^{* *}$ significant at $5 \%$.

\section{C. limitations}

According to the regulations of Chinese Foundation Management Regulations, we divide charitable foundations into two types which include public offering charitable foundations and non-public offering charitable foundations. The empirical analyses find that some financial information has influenced on donations. But I wonder whether the results will be different if we divide charitable foundations into other types according to other classification standards. Through empirical analysis, we do not find the relationship between some expenditure financial information of charitable foundations and donations. In addition, the regression model built can only use financial information ratio as dependent variables. I wonder whether some other dependent variables just as government variables used in the regression model would come to the different results. Our results may not hold for all the influence of financial information used by other organizations. While we have attempted to control for the effect of other factors, further research is needed to fully analyze this issue.

\section{CONCLUSIONS}

This study establishes a framework that identifies the constructs represented by the variables used in previous accounting studies (Parsons, 2008). Our framework demonstrates that financial information from charitable foundations' financial report can be categorized into three major constructs, each of which is an important determinant of donations. Table 7 presents the three major constructs, which has positive or negative influence on donations.

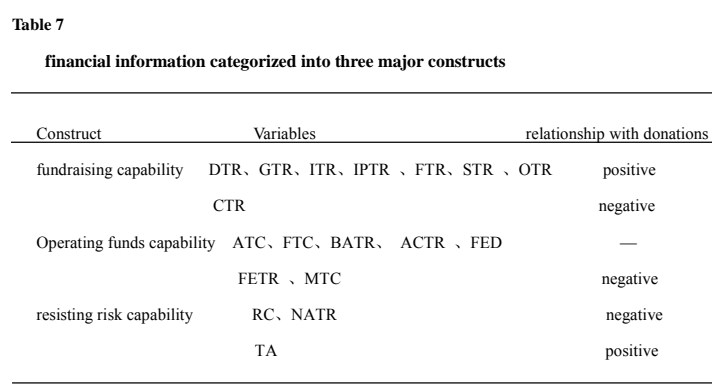

Many donors want to make informed decisions about which organizations are worthy recipients. Financial information is the most important for donors. Accordingly, research aimed at understanding the impact of all kinds of financial information issued from charitable foundations' report is useful for determining whether these organizations are making the market for donations more efficient.

Our findings indicate that contributions are sensitive to financial information. The operating expenditure is a main cost of charitable foundations. The second mainly expenditure is the management expense of charitable foundations. The fundraising cost a little below the above mentioned expenditure of charitable foundations. The donation income is main income in Chinese public offering charitable foundations, which comes from fundraising of major public projects. Public and non-public offering charitable foundations mainly depend on the certain income sources. The results show that the risk of fundraising of non-public offering charitable foundations is higher than public offering charitable foundations'.

The financial information of public offering charitable foundations has some different influence on individual donations and institution donations. When an institution makes decision to donate to public offering charitable foundations, it will consider much more financial information than a person makes decision to donate to public offering charitable foundations. Actually an institution donation has been influenced by financial information reflecting income structure, operating expenditure, and revenue concentration. The individual donation has been influenced by financial information reflecting income structure and total assets. The same financial information of non-public offering charitable foundations has influence on the individual donations and institution donations. The analytical results present that institution donations is easier to be influenced by financial information of non-public offering charitable foundations than individual donations

\section{REFERENCES}

[1] Akerlof, G., 1970.The market for "lemons": quality uncertainty and the marketmechanism.Quarterly Journal of Economics 90,629-650.

[2] Altaf Merchant, John B. Ford b,1, Adrian Sargeant.,2010. Charitable organizations' storytelling influence on donors' emotions and intentions. Journal of Business Research 63,754-762.

[3] Bushman, R., Piotroski, J., Smith, A.. ,2004. What determines corporate transparency?. Journal of Accounting Research 42,207-252.

[4] Baber, W. R., Roberts, A. A., \& Visvanathan, G.,2001. Charitable organizations' strategies and program-spending ratios. Accounting Horizons 15(4),329-343

[5] Bradley, B., Jansen, P., \& Silverman, L..,2003.The nonprofit sector's $\$ 100$ Billion opportunity. Harvard Business Review 81(5),94-103. 
[6] Chia-Wulu,Tsung-KangChen,Hsien-Hsing.Liao.,2010.Information .unce rtainty,information asymmetry and corporate bond yield spreads.Journal of Banking\&Finance 34,2265-2279.

[7] Eckel, C. C., and P. J. Grossman., 2003.Rebate versus matching: Does how we subsidize charitable contributions matter?. Journal of Public Economics 87 (3-4), 681-701.

[8] Frumkin, P., \& Kim, M. T. . ,2001.Strategic positioning and the financing of nonprofit organizations: Is efficiency rewarded in the contributions marketplace? . Public Administration Review 61(3),266-275.

[9] Greenlee, J. S., and K. L. Brown.,1999.The impact of accounting information on contributions to charitable organizations. Research in Accounting Regulation 13,111-125.

[10] Greenlee, J. S., \& Trussel, J. M..,2000. Predicting the financial vulnerability of charitable Organizations. Nonprofit Management and Leadership 11(2),199-210.

[11] Gordon, T. P., \& Khumawala, S. B. ,1999.The demand for nonprofit financial statements: A model for individual giving. Journal of Accounting Literature 18,31-56.

[12] Gordon, T. P., Knock, C.L., Neely, D.G., 2009.The role of rating agencies in the market for charitable contributions: an empirical test. Journal of Accounting and public Policy28,469-484.

[13] Hyndman, N., McMahon, D.,2010.The evolution of the UK charity Statement of Recommended Practice: The influence of key stakeholders European Management Journal28,455-466.

[14] Hyndman, N.,1990.Charity accounting - an empirical study of the information needs of contributors to UK fund raising charities. Financial Accountability and Management6(4), 295-307.

[15] Heflin FL, Shaw KW, Wild JJ.,2005.Disclosure policy and market liquidity: impact of depth quotes and order sizes. Contemp Account Res22(4),829-65.

[16] Hagerman RL, Healy JP.,1992.The impact of SEC-required disclosure and insider-trading regulations on the bid-ask spreads in the over-the-counter market.Account Public Policy12(3),233-43.

[17] Hansmann, H. B.,1980.The role of nonprofit enterprise. The Yale Law Journal89(5), 835-901.

[18] Khumawala, S. B., \& Gordon, T. P,1997.Bridging the credibility of GAAP: Individual donors and the new accounting standards for nonprofit organizations.Accounting Horizons11(3),45-68.

[19] Leuz C, Verrecchia RE.,2000.The economic consequences of increased disclosure. Accounting Reseach 38,91-124.

[20] Marudas, N. P. ,2004. Effects of nonprofit organization wealth and efficiency on private donations to large nonprofit organizations.Research in Governmental and Nonprofit Accounting11, 71-91.

[21] Parsons, L. M.,2003. Is accounting information from nonprofit organizations useful to donors? A review of charitable giving and value-relevance. Journal of Accounting Literature22,104-129.

[22] Parsons, L. M..,2007.The impact of financial information and voluntary disclosures on contributions to not-for-profit organizations.Behavioral Research in Accounting 19,179-196.

[23] Parsons, L. M., \& Trussel, J. M.,2008.Fundamental analysis of not-for-profit financial statements: An examination of financial vulnerability measures.Research in Governmental and Nonprofit Accounting12,216-218.

[24] Paul M. Healy,Krishna G. Palepu.,2001.Information asymmetry, corporate disclosure, and the capital markets:A review of the empirical disclosure iterature. Journal of Accounting and Economics31,405-440.

[25] Ronald A. Dye.,2001.An evaluation of "essays on disclosure" and the disclosure literature in accounting. Journal of Accounting and Economics32,181-235

[26] Robert E.Verrecchia.,2001.Essays on disclosure. Journal of Accounting and Economics 32,97-180.

[27] Roberts, A. A., Smith, P., \& Taranto, K. ,2006.Evaluating charitable spending: Marginal versus average performance measures .USA: Boston College, University of Texas at San Antonio and Georgetown University.
[28] Teresa P. Gordon, Cathryn L. Knock1, Daniel G. Neely.,2009.The role of rating agencies in the market for charitable contributions: An empirical test.Journal of Accounting and Public Policy28,469-484.

[29] Tuckman, H. P., \& Chang, C. F.,1991.A methodology for measuring the financial vulnerability of charitable nonprofit organizations.Nonprofit and Voluntary Sector Quarterly20(4), 445-460.

[30] Trussel, J. M., \& Greenlee, J. S.,2004.A financial rating system for charitable nonprofit organizations.Research in Government and Nonprofit Accounting11,93-116.

[31] Tinkelman, D.,1999.Factors affecting the relation between donations to nonprofit organizations and an efficiency ratio.Research in Government and Nonprofit Accounting10, 135-161.

[32] Chen Xiwu, Ji Gang.,2008.Non-profit organization information disclosure mechanism: a theoretical framework.Finance and trade research4,111-117.

[33] Chen Xiaolin, Wei Xueqiang.,2011.Enterprise donation motives, influence factors and economic consequences.Friends of the accounting 4,7-10.

[34] Jiang Linlin.,2011.The biggest challenge of the charity organization is to satisfy demand donors. South people weekly30,34.

[35] Yu Guowang.,2010.The entrusted responsibility and non-profit organization accounting information disclosure analysis.Accounting communication (comprehensive) 8,53-54.

[36] Yang Pingbo.,2010.Under the perspective of Property rights of non-public charitable foundation information disclosure .Accounting monthly5,36-37.

[37] Zhang Biao.,2009.Non-governmental organization performance of financial evaluation index system design.Statistics and decision9,174-176.

[38] Zhao Jing.,2011.Construction the financial performance evaluation index system of Non-profit organization.Economic research guide1,83-85.

[39] Zhao Xiaoqin, Wan Difang.,2011.Affect China enterprise charity donation behavior factor: provincial space relevant perspective - based on "5 - 12" earthquake mainland econometric analysis of enterprise donation. Soft science25(5),120-123.

[40] Accounting Standards of Not-profit Organizations,2004.Ministry of Finance the People's Republic of China.

[41] [Foundation Management Regulation,2004.Decree of State council of the People's Republic of China. 